\title{
Science Reseurch Council Advises the Government
}

WITH the government departments in the throes of reorganization for the coming of the customer-contractor principle, the annual report of the Science Research Council this week gives advice on how to run the system (Science Research Council Annual Report, Cmnd 458, HMSO £0.73).

The council insists that most of the research and development financed by the government, in particular that through the research councils, is for the general benefit of the community rather than for direct application by government departments. To ensure that industry and the professions derive full benefit from the results, the council calls on the government to ensure that the professions, universities, polytechnics, research councils, executive departments, NRDC and other government agencies "work as an integrated whole to choose national research and development programmes and to ensure the application of the results to the nation's wealth and well-being".

The council also points out that applied research and development carried out with a particular application in view is often more expensive than basic research and that, if work like this is to be properly controlled, it must have specific objectives. Until sufficient basic research has been carried out, applied research and development programmes will be premature, says the council, and will lead to "waste and duplication". The advantages of an applied research programme, however, is that gaps in knowledge emerge which can be made good with further basic research.

Having established, in principle, the need for both basic and applied research programmes, the Science Research Council goes on to say that each department "should certainly be responsible for commissioning the applied research and development which it needs... or for whose potential users it is manifestly the best sponsor department", but according to the report the departments should also influence the allocation of all funds for research and development programmes, including the science budget of the Department of Education and Science. In addition, the SRC calls on the departments to influence the allocation of funds between the individual councils and also to influence the research programmes of the councils.

The SRC also reiterates its warning to the government that the customer- contractor principle will not be successful without "strong chief scientist organizations which command the confidence and respect of the scientific community".

Politics apart, the council reports that during $1971-72$ it spent $£ 59.96$ million, an increase of $£ 8.6$ million over 1970 71. Of this sum $£ 8.47$ million was allocated to CERN, $£ 4.7$ million to ESRO and $£ 415,000$ to NATO scientific schemes. During the year, the SRC awarded 1,676 research grants compared with 1,501 the previous year. Engineering subjects were given priority but science subjects also showed some growth.

The SRC spent $£ 42.66$ million of its funds in universities, technical colleges or other institutions in 1971-72 with the University of Cambridge heading the list with $£ 4.43$ million. Of this the university's control engineering department was supported to the tune of $£ 750,000$, astronomy received $£ 664,000$ and mechanical and production engineering $£ 572,000$. The University of Oxford received $£ 3.91$ million with the Nuclear Physics Department receiving the lion's share of $£ 601,000$.

During 1971-72, the SRC lifted its restriction on the numbers of research assistant posts in universities except in nuclear physics. The council felt able to do this because of the apparent surplus of scientists and engineers.

The council, for the first time, is able to plan two years ahead instead of one. The proposed support for 1974-75, however, is less than the council needsshowing an increase in real terms of only 2.5 per cent over 1973-74-and the council emphasizes that the gap

\section{RADIOCHEMICALS \\ Active Centre}

IN spite of increased costs, resulting from the Radiochemical Centre Ltd being granted independent status in February 1971, the company's first annual report published last week shows a healthy profit of $£ 816,000$, thirty-five per cent more than achieved in 1970-71 (First Annual Report, The Radiochemical Centre Ltd, Amersham).

During the year, sales increased by 22 per cent over those made by the centre during the days when it was a part of the United Kingdom Atomic Energy Authority. An eighteen per cent return on capital was obtained, three per cent more than in 1970-71, but the return on between its resources and the needs of the expanding universities and polytechnics will widen. In spite of these difficulties the council has decided to increase the number of post graduate awards in 1973 by three per cent but this autumn will issue the same number as last year.

The council says that the Mark VA radio telescope, which it is hoped will be built at Meifod in mid-Wales, the Northern Hemisphere Observatory and a millimetre wavelength facility are to be given priority. The report also mentions that the Astronomy, Space and Radio Board are considering alternative research opportunities for British scientists who have been affected by the reduction in the ESRO scientific programme.

Nuclear physics, for which the SRC provided $£ 1.91$ million in 1971-72 in universities and elsewhere, will, the council hopes, be supported to the same extent in real terms in the future. The $300 \mathrm{GeV}$ project at CERN will have the highest priority but the council says that it also hopes to build the nuclear structure facility at Daresbury, which has recently been shown to be a viable project (Nature, 237, 192; 1972).

The company, however, believes that of its three chief areas of business radiochemicals, radiopharmaceuticals and radiation sources-prospects of expansion are greatest in the radiopharmaceutical field, but to maintain its share of the market the report says that a flow of new products is needed. To increase its share of the market, according to the report, this must be coupled with a superior marketing and technical service.

sales of 14 per cent is the same as obtained the previous year. The company is paying a 10 per cent dividend but it is still able to add $£ 293,000$ to its capital.

During the year, new pharmaceutical laboratories and dispensaries were commissioned at a cost of $£ 1$ million. The cyclotron which the centre uses to produce isotopes has, as well, been modified to improve its stability.

The company, in spite of its bright first year, is reluctant to make firm predictions for the future. With most of the company's products being sold abroad- $-£ 3.72$ million worth last yearits income is dependent on exchange rates and, according to the report, competition is becoming stronger. 